\title{
Widespread Usutu virus outbreak in birds in the Netherlands, 2016
}

J Rijks ${ }^{12}$, M Kik ${ }^{123}$, R Slaterus ${ }^{4}$, R Foppen ${ }^{45}$, A Stroo 6 , J IJzer ${ }^{13}$, J Stahl 4 , A Gröne ${ }^{13}$, M Koopmans ${ }^{7}$, H van der Jeugd 8 , C Reusken ${ }^{7}$

1. Dutch Wildlife Health Centre (DWHC), Utrecht University, Utrecht, The Netherlands

2. These authors contributed equally to the work

3. Veterinary Pathology Diagnostic Centre (VPDC), Division of Pathology, Department of Pathobiology, Utrecht University, Utrecht, The Netherlands

4. Sovon, Dutch Centre for Field Ornithology, Nijmegen, The Netherlands

5. Department of Animal Ecology, Institute for Water and Wetland Research, Radboud University Nijmegen, The Netherlands

6. Centre for Monitoring of Vectors (CMV), National Reference Centre (NRC), Netherlands Food and Consumer Product Safety Authority (NVWA), Ministry of Economic Affairs, Wageningen, The Netherlands

7. ErasmusMC, Department of Viroscience, Rotterdam, The Netherlands

8. Vogeltrekstation - Dutch Centre for Avian Migration and Demography (NIOO-KNAW), Wageningen, The Netherlands

Correspondence: Jolianne M. Rijks (j.m.rijks@uu.nl)

Citation style for this article:

Rijks J, Kik M, Slaterus R, Foppen R, Stroo A, IJzer J, Stahl J, Gröne A, Koopmans M, van der Jeugd H, Reusken C. Widespread Usutu virus outbreak in birds in the Netherlands, 2016. Euro Surveill. 2016;21(45):pii=30391. DOI: http://dx.doi.org/10.2807/1560-7917.ES.2016.21.45.30391

Article submitted on 18 October 2016 / accepted on og November 2016 / published on 10 November 2016

We report a widespread Usutu virus outbreak in birds in the Netherlands. Viral presence had been detected through targeted surveillance as early as April 2016 and increased mortality in common blackbirds and captive great grey owls was noticed from August 2016 onwards. Usutu virus infection was confirmed by postmortem examination and RT-PCR. Extensive Usutu virus activity in the Netherlands in 2016 underlines the need to monitor mosquito activity and mosquitoborne infections in 2017 and beyond.

Here we describe the detection of Usutu virus (USUV; genus Flavivirus, family Flaviridae), a potentially zoonotic mosquito-borne virus, in live birds captured in the Netherlands in April 2016, and the development of an USUV outbreak with mortality in birds first noticed in August 2016. We provide details on pathological findings in common blackbirds (Turdus merula; $\mathrm{Tm}$ ) and great grey owls (Strix nebulosa; Sn) and give information on the size of the outbreak, as well as on mosquito abundance in 2016.

\section{Subclinical bird cases}

As part of a targeted study looking at potential routes of incursion of arboviruses, live birds have been captured for sample collection since March 2016. USUV RNA was detected in throat swabs from two healthy blackbirds caught near Wageningen (Gelderland Province) in early April, based on RT-PCR detection of two independent USUV genome targets and sequencing of a $214 \mathrm{bp}$ genome fragment generated in a third, pan-flavi RT-PCR $[1,2]$.

\section{Outbreak in birds}

\section{Outbreak identification (first set of birds)}

The first evidence for an outbreak was obtained in the period from 28 August to 13 September 2016, when an increasing number of case reports of disease-associated mortality in blackbirds were put forward through a citizen science-based alerting system (Table 1). In parallel, the number of blackbirds submitted for postmortem examination in the context of wildlife disease scanning increased. Eighteen blackbirds were submitted in 2016 until 13 September, and among these one (Tm 1) was obtained on 10 August 2016 and 12 (Tm 2-12, plus one autolytic specimen) were obtained from 28 August onwards (Table 1). Tm 1-12 were from 11 different sites.

During the same period, the deaths of four captive great grey owls (Sn 1-4) were investigated. The deaths occurred between 13 August and 12 September 2016, in three facilities. The post-mortem findings in birds Tm 1-12 and Sn 1-4 are summarised in Table 2.

Initially, based on the presence of Plasmodium spp. schizonts and mixed inflammatory infiltrates in mainly liver and spleen, avian malaria was diagnosed (Tm 1-3, 5) $[3,4]$. However, when birds had myocardial degeneration (Tm 4) or encephalitis ( $\mathrm{Tm} 7-8, \mathrm{Sn} 4)$, tissues were submitted for USUV RT-PCR. USUV was detected in eight of 12 blackbirds ( $\operatorname{Tm~4,~6-12)~and~all~four~great~}$ grey owls (Table 2). USUV-positive cases came from sites located in the south-east of the Netherlands (Figure 1, first set). Public health authorities were 
Spatial distribution of the common blackbird and great grey owl specimens tested for Usutu virus infection and common blackbird mortality as reported by the public, the Netherlands, 1 August-23 September 2016 (inset: common blackbird density 2013-15)

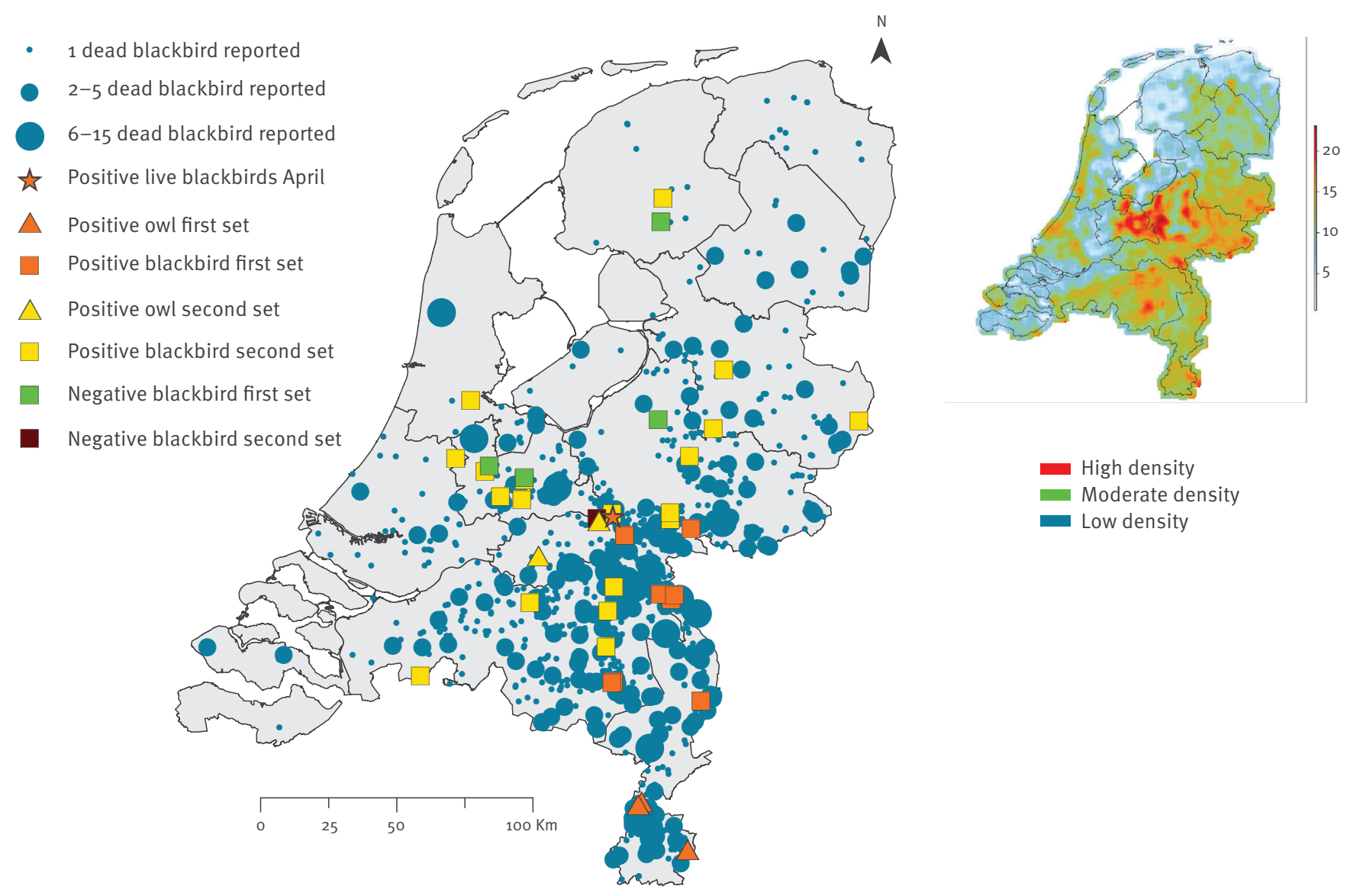

First set: the birds examined post mortem from 1 August to 13 September 2016; second set: those obtained from 14 to 23 September 2016.

informed of the outbreak, followed by a press release to inform the public on 15 September 2016.

Scale of the outbreak (second set of birds) To gain insight in the spatial distribution of the USUV outbreak, more information was collected on deaths among blackbirds and great grey owls outside the initially identified area of USUV activity (south-east of the Netherlands). The number of reported dead blackbirds per location was extracted from reports by the public to Sovon or the Dutch Wildlife Health Centre from 1 August to 23 September 2016 and mapped using ArcGIS software by Esri (Figure 1). To visually compare this with the blackbird population density, a species distribution model was made based on more than 10,000 standardised five-minute bird counts performed during the breeding seasons from 2013 to 2015, according to a fixed grid and a large set of explanatory variables [5] (Figure 1 inset). A selection of dead blackbirds and great grey owls notified for submission by the public or owl owners between 14 to 23 September were collected for USUV testing. The selection was based on how fresh the carcass was and whether it was found at a location where USUV activity had not been identified before.

There were 924 citizen reports of which 226 mentioned that multiple sick or dead blackbirds had been observed. Most reports were from September (885/924, $96 \%$ ) and from the provinces Noord Brabant (293/924, $32 \%)$, Gelderland $(261 / 924,28 \%$ ) and Limburg (148/924, 16\%). Between 14 and 23 September, 20 dead blackbirds and two great grey owls were collected for USUV testing. Nineteen of the blackbirds and two of the great grey owls tested positive for USUV (Figure 1 , second set). These data support widespread occurrence of USUV infection in birds in the Netherlands in September 2016.

\section{Vector abundance}

Long-term standardised datasets on mosquito abundance are not available in the Netherlands, and arbovirus surveillance in mosquitoes is not performed. An indication of mosquito abundance in 2016 relative to previous years was obtained from data on mosquitoes found at four locations, with bi-weekly collection 
Common blackbirds (Turdus merula) observed by citizens to die of disease $(n=136)$ and those submitted for post-mortem examination $(\mathrm{n}=115)$, the Netherlands, 2005-16

\begin{tabular}{|c|c|c|c|}
\hline \multirow[t]{2}{*}{ Time period } & \multicolumn{2}{|c|}{$\begin{array}{l}\text { Proportion of dead blackbirds reported to Sovon }{ }^{a} \text { with 'disease' as } \\
\text { the cause of death }\end{array}$} & \multirow{2}{*}{$\begin{array}{c}\text { Dead blackbirds investigated at } \\
\text { DWHC }^{\mathrm{b}} \\
\text { Number }\end{array}$} \\
\hline & Disease/total deaths & $\%$ & \\
\hline 2005 & $0 / 11$ & 0 & NA \\
\hline 2006 & $0 / 367$ & 0 & NA \\
\hline 2007 & $0 / 232$ & 0 & NA \\
\hline 2008 & $1 / 160$ & 1 & 0 \\
\hline 2009 & $109 / 473^{c}$ & 23 & 4 \\
\hline 2010 & $1 / 161$ & 1 & 12 \\
\hline 2011 & $0 / 111$ & 0 & 3 \\
\hline 2012 & $13 / 388$ & 3 & $49^{d}$ \\
\hline 2013 & $1 / 103$ & 1 & 18 \\
\hline 2014 & $2 / 102$ & 2 & 5 \\
\hline 2015 & $0 / 120$ & 0 & 6 \\
\hline $\begin{array}{l}2016 \text { until } 13 \\
\text { Sep }\end{array}$ & $9 / 95^{\mathrm{e}}$ & 9 & $18^{\mathrm{e}}$ \\
\hline
\end{tabular}

NA: not available.

a Dutch Centre for Field Ornithology, Nijmegen.

${ }^{b}$ Dutch Wildlife Health Centre, Utrecht (operational in Utrecht from 2008 onwards).

c All reports indicating blackbirds that died of disease were preceded by the press paying attention to the Trichomonas gallinae finch epidemic.

${ }^{d}$ Fourty-seven of the blackbirds were obtained following the reports in the national press on Usutu virus infection in Germany and a press release on 7 October requesting the public to submit dead blackbirds. There was no evidence for Usutu virus infection at the time [1].

e Among these, eight of nine diseased birds reported to Sovon and 12 of 18 submissions to DWHC were obtained during the 16 -day window from 28 August to 13 September. These increasing numbers were not triggered by media attention.

of mosquitoes carried out during the summer period in the years 2014 to 2016 using one trap design (BG-sentinel trap, Biogents, Germany) at sites where no insecticide treatment was applied. The total number trapped across sites in $2016(n=25,693)$ was approximately six times greater than in $2014(\mathrm{n}=4,558)$ and approximately 10 times greater than in $2015(n=2,615)$ (Figure 2). None of the mosquito samples were tested for USUV.

\section{Discussion}

There is a widespread USUV outbreak in wild blackbirds and captive great grey owls in the Netherlands. Although USUV circulated in neighbouring countries, it had not been detected in the Netherlands before 2016, despite scanning surveillance for bird mortality since 2008 and a targeted study in dead blackbirds based on convenience sampling in 2012 [1]. USUV emerged in Europe in Italy 20 years ago [6]; however, introductions from Africa probably started several decades earlier and continue to occur [7]. The virus has been detected in mosquitoes, birds and bats in eight European countries (Austria, Belgium, Czech Republic, Germany, Hungary, Italy, Spain, Switzerland) [7,8] and is presumably maintained in enzootic mosquito-bird transmission cycles. Birds of 14 orders can be infected [8]. In the current outbreak in the Netherlands, live bird monitoring showed the presence of the virus in wild birds already months before the detection of unusual death rates among blackbirds and great grey owls. USUV outbreaks also occurred in birds in neighbouring countries, Belgium and Germany, in 2016 (personal communication: M. Garigliany and J. Schmidt-Chanasit, August 2016). A comprehensive genetic study including strain data from affected neighbouring countries is underway to elucidate the origin of events and patterns of spread.

High mosquito abundance may have been one of the factors contributing to the occurrence and scale of the outbreak in the Netherlands. In Europe, the Culex pipiens mosquito is considered an important vector for USUV $[9,10]$. The Culex pipiens/torrentium complex is found throughout the Netherlands between April and October [11]. June 2016 was extremely wet and, together with unusually high temperatures in September, may have furthered and prolonged mosquito activity $[12,13]$. The event demonstrates the need for long-term standardised datasets on mosquito abundance in the Netherlands and their analysis in relation to climate. The samples of captured mosquitoes could be one pillar in a molecular surveillance programme for USUV and other mosquito-borne zoonotic viruses.

In birds, fatal infections occur mostly in Passeriformes and Strigiformes $\left[9,14^{-17}\right]$. Hepatosplenomegaly is a common finding. Histological lesions include encephalitis and necrosis in heart, liver, spleen and kidney, 
TABLE 2

Pathological findings in the common blackbirds (Tm 1-12) and great grey owls (Sn 1-4) submitted, grouped by detected infectious agent(s), the Netherlands, 1 August-13 September

\begin{tabular}{|c|c|c|c|c|c|}
\hline & \multicolumn{3}{|c|}{ Blackbird } & \multicolumn{2}{|l|}{ Owl } \\
\hline & $\operatorname{Tm} 1-3,5$ & $\operatorname{Tm} 4,7,8,11,12$ & $\operatorname{Tm} 6,9,10$ & Sn $1-3$ & Sn 4 \\
\hline Infectious agent(s) detected ${ }^{a}$ & Only Plasmodium & $\begin{array}{l}\text { Plasmodium and } \\
\text { USUV }\end{array}$ & Only USUV & Plasmodium and USUV & Only USUV \\
\hline \multicolumn{6}{|l|}{ Gross lesions ${ }^{\mathrm{b}, \mathrm{c}}$} \\
\hline Hepatomegaly & $4 / 4$ & $3 / 5$ & $1 / 3$ & $2 / 3$ & $1 / 1$ \\
\hline Splenomegaly & $4 / 4$ & $4 / 5$ & $3 / 3$ & $3 / 3$ & $1 / 1$ \\
\hline Lung hyperaemia, oedema & $2 / 4$ & $3 / 5$ & $1 / 3$ & $2 / 3$ & $1 / 1$ \\
\hline Heart abnormalities & $\begin{array}{c}2 / 4 \\
\text { (1 haemopericardium, } 1 \\
\text { pale) }\end{array}$ & $\begin{array}{c}1 / 5 \\
(1 \mathrm{pale})\end{array}$ & $0 / 3$ & $\begin{array}{c}1 / 3 \\
\text { (1 hydropericardium) }\end{array}$ & $0 / 1$ \\
\hline Skin by cloaca firm, crusty & $2 / 4$ & $5 / 5$ & $1 / 3$ & $0 / 3$ & $0 / 1$ \\
\hline Feather abnormalities & $0 / 4$ & $\begin{array}{c}2 / 5 \\
(1 \mathrm{rfsh}, 1 \mathrm{blood} \\
\text { pens })\end{array}$ & $\begin{array}{c}2 / 3 \\
\text { (2 featherless } \\
\text { heads) }\end{array}$ & $0 / 3$ & $0 / 1$ \\
\hline \multicolumn{6}{|l|}{ Histological lesions ${ }^{b, c}$} \\
\hline Encephalitis & $0 / 3$ & $\begin{array}{c}2 / 4 \\
(1 \mathrm{pvc}, 1 \mathrm{gli} / \mathrm{deg} / \\
\mathrm{pvc} / \mathrm{swe})\end{array}$ & $\begin{array}{c}1 / 3 \\
(1 \mathrm{pvc})\end{array}$ & $0 / 3$ & $\begin{array}{c}1 / 1 \\
(1 \mathrm{mix} / \mathrm{gli})\end{array}$ \\
\hline Myocardial degeneration & $0 / 4$ & $1 / 5$ & $1 / 3$ & $0 / 3$ & $1 / 1$ \\
\hline Myocarditis & $\begin{array}{c}3 / 4 \\
\text { (1 het, } 2 \text { lym, } 1 \text { pvc) }\end{array}$ & $\begin{array}{c}3 / 5 \\
(1 \mathrm{pvc} / \mathrm{swe}, 2 \mathrm{lym} / \\
\text { int } / \pm \mathrm{pvc})\end{array}$ & $\begin{array}{c}2 / 3 \\
(1 \mathrm{lym}, 1 \text { nec) }\end{array}$ & $0 / 3$ & $0 / 1$ \\
\hline Pneumonia & $\begin{array}{c}3 / 4 \\
(3 \mathrm{mix}) \\
\end{array}$ & $\begin{array}{c}3 / 5 \\
(2 \text { lym/int, } 1 \mathrm{mix}) \\
\end{array}$ & $\begin{array}{c}2 / 3 \\
(2 \text { lym/int) }\end{array}$ & $\begin{array}{c}3 / 3 \\
\text { (2 het, } 1 \text { mix) }\end{array}$ & $\begin{array}{c}1 / 1 \\
(1 \text { lym/int/nec) } \\
\end{array}$ \\
\hline Kidney epithelial necrosis & $1 / 3$ & $4 / 5$ & $1 / 3$ & $0 / 3$ & $0 / 1$ \\
\hline Hepatitis & $\begin{array}{c}4 / 4 \\
(4 \mathrm{mix})\end{array}$ & $\begin{array}{c}4 / 5 \\
\text { (4 mix } \pm \text { nec) }\end{array}$ & $\begin{array}{c}3 / 3 \\
(1 \mathrm{lym} / \mathrm{nec}, 2 \\
\mathrm{mix})\end{array}$ & $\begin{array}{c}2 / 2 \\
(1 \mathrm{mix} / \mathrm{nec}, 1 \text { het })\end{array}$ & $\begin{array}{c}1 / 1 \\
(1 \mathrm{nec})\end{array}$ \\
\hline Splenitis & $\begin{array}{c}2 / 3 \\
(2 \mathrm{mix})\end{array}$ & $\begin{array}{c}4 / 5 \\
(3 \mathrm{mix}, 1 \mathrm{nec})\end{array}$ & $\begin{array}{c}1 / 2 \\
(1 \mathrm{lym} / \text { nec })\end{array}$ & $\begin{array}{c}3 / 3 \\
(1 \mathrm{mix} / \mathrm{nec}, 2 \mathrm{nec})\end{array}$ & $\begin{array}{c}1 / 1 \\
(1 \text { nec })\end{array}$ \\
\hline Haemosiderosis & $2 / 4$ & $4 / 5$ & $1 / 3$ & $2 / 3$ & $0 / 1$ \\
\hline Skin cloaca dermatitis & $\begin{array}{c}2 / 4 \\
(2 \mathrm{mix})\end{array}$ & $\begin{array}{c}4 / 4 \\
\text { (2 mix, } 2 \text { lym) }\end{array}$ & $\begin{array}{c}1 / 2 \\
(1 \text { lym })\end{array}$ & $0 / 3$ & $0 / 1$ \\
\hline
\end{tabular}

Deg: degeneration of white matter; gli: satellitosis, gliosis; het: heterophilic infiltrates; int: interstitial infection; lym: lymphoplasmacytic infiltrates (lymphocytes, plasma cells, histiocytes); mix: mixed infiltrates; nec: necrosis; pvc: perivascular cuffing; rfsh: retained feather shafts; Sn: Strix nebulosa; swe: endothelial cell swelling; Tm: Turdus merula; USUV: Usutu virus.

a Plasmodium infection was determined by cytology and histology, USUV infection by RT-PCR test on brain, spleen, heart and/orliver.

b Number of cases positive/total number of cases examined.

c Incidental findings included gastrointestinal worms in eight of 12 blackbirds and a mycotic infection in the glandular stomach of one owl.

with lymphoplasmacytic inflammation [9,14-17]. In this outbreak, the pathological findings raised two questions. Firstly, many of the birds were co-infected with Plasmodium spp. Mosquitoes are the vectors of both USUV and Plasmodium spp., which may explain the high number of dual infections. Alternatively, a fatal outcome of USUV infection may be more probable in co-infection. Secondly, while skin lesions during USUV outbreaks have been reported earlier $[9,18]$, causal association is unknown and needs to be studied.

We used citizen science data to identify the area where the virus probably circulated most intensively up to 23 September 2016. Infected blackbirds maintain virus circulation [15], and the observed pattern will partly reflect the density of resident blackbird populations.
Ongoing wild bird counts will provide insight into the impact of USUV on resident bird populations.

The emergence of USUV in the Netherlands illustrates the continuous geographical expansion of zoonotic arboviruses in Europe, documented elsewhere [8]. It serves as another warning of the expanding geographical range of regions suitable for sustained arbovirus circulation. In areas with endemic circulation, human infections seem to occur very rarely with only 13 human cases described in literature until now [19]. Human clinical cases present with neurological signs, fever, rash, jaundice or combinations thereof. Subclinical human USUV infections are a concern in blood transfusions or organ transplants [20], and recent data from Italy suggest that subclinical cases in regions with sustained 


\section{FIGURE 2}

Cumulative number of mosquitoes found per year, at the sites of four used tyre companies, the Netherlands, week 22 to week 37 (end of May to mid-September)

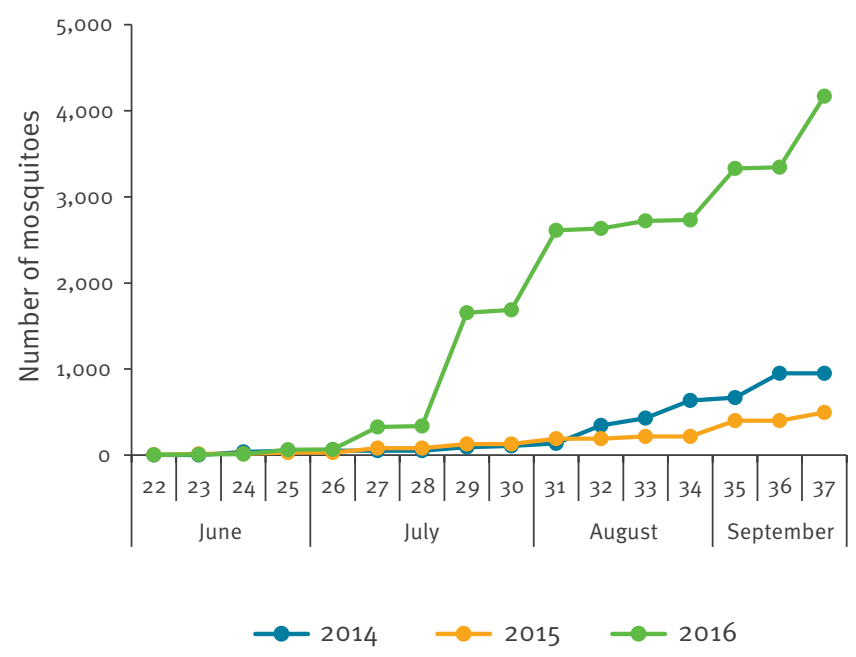

The tyre companies were located throughout the country: Leeuwarden (north), Amsterdam (west), Tilburg (south) and Nederweert (east).

USUV circulation may be more common than previously thought [19]. The same study showed that USUV was the cause of previously unexplained encephalitis cases [19], indicating that USUV should be included in the differential diagnosis of such cases in endemic areas. These recent public health findings suggest that USUV diagnostic capability and adequate USUV surveillance with molecular typing are warranted in regions shown to be suitable for USUV circulation. Although the 2016 mosquito season is coming to an end, physicians should be aware of putative USUV infection in cases of viral encephalitis of unknown aetiology, and vigilance should be maintained in the coming mosquito season in 2017.

\section{Acknowledgements}

We thank the general public and bird ringers for reporting mortality and submitting specimens; Alphons van Asten, Hanna Hesselink and Margriet Montizaan for administrative assistance; Natashja Buijs, Andrea Laumen and Ruby Wagensveld for assistance with the post-mortem examinations; Tess van de Voorde for help with the live bird surveillance; Anne van der Linden and Robert Kohl for assistance in the laboratory work; Christian Kampichler for assistance with preparing the common blackbird density map; Jeroen Nienhuis for assistance with the baseline Sovon data. Funding statement: Scanning surveillance of dead wild birds is funded by the Dutch Ministry of Economic Affairs grant number 1300022600 . The Eco-Alert project (live bird surveillance) is funded by ZonMW grant number 50-5220098-026. The bird atlas project (blackbird density map) is a Citizen Science census initiative of Sovon Dutch Centre for Field Ornithology. There is no competing interest. Approval of the work by an ethics committee is not required for scanning surveillance of dead wild birds. Surveillance of live birds within EcoAlert is performed under license AVD/263002015342 to Vogeltrekstation NIOO-KNAW.

\section{Conflict of interest}

None declared.

\section{Authors' contributions}

Manuscript writing JMR, MLK, RPBF, AS and CBEMR. Pathology MLK, JI and AG. Virology CBEMR. Live bird surveillance CBEMR, HVDJ and MGPK. Common blackbird density data RPBF. Mosquito abundance data AS. Citizen science data JMR, RS, RPBF and JS. All authors critically read the manuscript.

\section{References}

1. Reusken C, Zutt I, Kik M, Cleton N, Rijks J, Schmidt-Chanasit J, et al. [No proof for usutuvirus as cause of death in songbirds in the Netherlands (fall 2012)]. Tijdschr Diergeneeskd. 2014;139(3):28-30. Dutch. PMID:24701786PMID: 24701786

2. Scaramozzino N, Crance JM, Jouan A, DeBriel DA, Stoll F, Garin D. Comparison of flavivirus universal primer pairs and development of a rapid, highly sensitive heminested reverse transcription-PCR assay for detection of flaviviruses targeted to a conserved region of the NS 5 gene sequences.J Clin Microbiol. 2001;39(5):1922-7. DOI: 10.1128/JCM.39-5.19221927.2001 PMID: 11326014

3. Vanstreels RE, Capellino F, Silveira P, Braga ÉM, RodríguezHeredia SA, Loureiro J, et al. Avian Malaria (Plasmodium spp.) in Captive Magellanic Penguins ( Spheniscus magellanicus) from Northern Argentina, 2010. J Wildl Dis. 2016;52(3):734-7. DOI: $10.7589 / 2015-08-219$ PMID: 27285418

4. Dinhopl N, Nedorost N, Mostegl MM, Weissenbacher-Lang C, Weissenböck $\mathrm{H}$. In situ hybridization and sequence analysis reveal an association of Plasmodium spp. with mortalities in wild passerine birds in Austria.Parasitol Res. 2015;114(4):145562. DOI: $10.1007 /$ so0436-015-4328-z PMID: 25636246

5. Schekkerman H, van Turnhout C, van Kleunen A, van Diek H, Altenburg J. Towards a new Dutch bird atlas: design of the fieldwork in 2012-2015. Limosa.2012;85:133-41.

6. Weissenböck H, Bakonyi T, Rossi G, Mani P, Nowotny N. Usutu virus, Italy, 1996.Emerg Infect Dis. 2013;19(2):274-7. DOI: 10.3201/eid1902.121191 PMID: 23347844

7. Engel D, Jöst H, Wink M, Börstler J, Bosch S, Garigliany MM, et al. Reconstruction of the Evolutionary History and Dispersal of Usutu Virus, a Neglected Emerging Arbovirus in Europe and Africa. MBio. 2016;7(1):e01938-15. DOI: 10.1128/mBio.01938-15 PMID: 26838717

8. Nikolay B. A review of West Nile and Usutu virus co-circulation in Europe: how much do transmission cycles overlap?Trans $\mathrm{R}$ Soc Trop Med Hyg. 2015;109(10):609-18. DOI: 10.1093/trstmh/ trvo66 PMID: 26286946

9. Becker N, Jöst H, Ziegler U, Eiden M, Höper D, Emmerich P, et al. Epizootic emergence of Usutu virus in wild and captive birds in Germany. PLoS One. 2012;7(2):e32604. DOI: 10.1371/ journal.pone.0032604 PMID: 22389712

10. Calzolari M, Gaibani P, Bellini R, Defilippo F, Pierro A, Albieri A, et al. Mosquito, bird and human surveillance of West Nile and Usutu viruses in Emilia-Romagna Region (Italy) in 2010. PLoS One. 2012;7(5):e38058. DOI: 10.1371/journal.pone.0038058 PMID: 22666446

11. Ibañez-Justicia A, Stroo A, Dik M, Beeuwkes J, Scholte EJ. National Mosquito (Diptera: Culicidae) Survey in The Netherlands 2010-2013.J Med Entomol. 2015;52(2):185-98. DOI: 10.1093/jme/tjuo58 PMID: 26336303

12. Royal Netherlands Meteorological Institute (KNMI). Recordnatte juni in het zuidoosten. [Record wet June month in the south-east]. De Bilt: KNMI; 14 July 2016. Dutch. Available from: https://www.knmi.nl/over-het-knmi/nieuws/ recordnatte-juni-in-het-zuidoosten

13. Royal Netherlands Meteorological Institute (KNMI). September 2016. Zeer warm, zeer droog en zeer zonnig. [September 2016. Very warm, dry and sunny]. De Bilt: KNMI; September 2016. Dutch. Available from: https://www.knmi.nl/nederland-nu/ klimatologie/maand-en-seizoensoverzichten/2016/september 
14. Weissenböck H, Kolodziejek J, Url A, Lussy H, Rebel-Bauder B, Nowotny N. Emergence of Usutu virus, an African mosquitoborne flavivirus of the Japanese encephalitis virus group, central Europe.Emerg Infect Dis. 2002;8(7):652-6. DOI: 10.3201/eido807.020094 PMID: 12095429

15. Chvala S, Kolodziejek J, Nowotny N, Weissenböck H. Pathology and viral distribution in fatal Usutu virus infections of birds from the 2001 and 2002 outbreaks in Austria.J Comp Pathol. 2004;131(2-3):176-85. DOI: 10.1016/j.jcpa.2004.03.004 PMID: 15276857

16. Steinmetz HW, Bakonyi T, Weissenböck H, Hatt JM, Eulenberger $\mathrm{U}$, Robert N, et al. Emergence and establishment of Usutu virus infection in wild and captive avian species in and around Zurich, Switzerland--genomic and pathologic comparison to other central European outbreaks. Vet Microbiol. 2011;148(24):207-12. DOI: 10.1016/j.vetmic.2010.09.018 PMID: 20980109

17. Höfle U, Gamino V, de Mera IG, Mangold AJ, Ortíz JA, de la Fuente J. Usutu virus in migratory song thrushes, Spain.Emerg Infect Dis. 2013;19(7):1173-5. DOI: 10.3201/eid1907.130199 PMID: 23764143

18. Bosch S. Zerzaust, gerupft oder glatzköpfig: Gefiederauffälligkeiten bei Amseln Turdus merula infolge einer Infektion mit Usutu-Viren? [Tousled, plucked or bald: feather anomalies in blackbirds Turdus merula following infection with Usutu viruses?]. Ornithologische Mitteilungen.2012;64(11/12):305-16. German.

19. Grottola A, Marcacci M, Tagliazucchi S, Gennari W, Di Gennaro A, Orsini M, et al. Usutu virus infections in humans: a retrospective analysis in the municipality of Modena, Italy. Clin Microbiol Infect. 2016;pii: S1198-743X(16)30425-6. doi: DOI: 10.1016/j.cmi.2016.09.019.

20. Allering L, Jöst H, Emmerich P, Günther S, Lattwein E, Schmidt $M$, et al. Detection of Usutu virus infection in a healthy blood donor from south-west Germany, 2012. Euro Surveill. 2012;17(50):20341.PMID: 23241231

\section{License and copyright}

This is an open-access article distributed under the terms of the Creative Commons Attribution (CC BY 4.0) Licence. You may share and adapt the material, but must give appropriate credit to the source, provide a link to the licence, and indicate if changes were made.

This article is copyright of the authors, 2016. 